\title{
The Changes of a Symbolic Meaning of Tedong in the Socio-Cultural and Economical Structure among the Devotees of Aluk Todolok Belief in Tana Toraja, South Sulawesi
}

\author{
$1^{\text {st }}$ Jumadi \\ Departement Sociological Science \\ Faculty of Social Science \\ Universitas Negeri Makassar \\ Makassar, Indonesia \\ Jumadi@unm.ac.id
}

\author{
$2^{\text {nd }}$ Nurlela \\ Department Antropology Science \\ Faculty of Social Science \\ Universitas Negeri Makassar \\ Makassar, Indonesia \\ nurlela@unm.ac.id
}

\author{
$3^{\text {rd }}$ Idham Irwansyah Idrus \\ Departemen of Sociology \\ Faculty of Social Science \\ Universitas Negeri Makassar \\ Makassar, Indonesia \\ idhamirwansyah@unm.ac.id
}

\begin{abstract}
This study aims to understand the symbolic change of meaning in the ceremony tedong Rambu Solo' or traditional rituals of death in people Aluk Todolok trust of Tana Toraja in South Sulawesi. The approach uses qualitative descriptive study, with the type of survey research. The focus of research is the symbolic meaning tedong (animal sacrifice) in the form of a buffalo in a traditional ritual in the community. Data analysis started from heuristic process (collecting data), criticism or verification, interpretation (interpretation) and writing the facts. The results showed that tedong in Tana Toraja society has a very high significance in social interactions in Tana Toraja society, especially in the implementation of the customary ritual of death according Aluk Todolok confidence. Tedong is a symbol of the meaning of the rules governing the implementation of the funeral ceremony, tedong has meaning economically for the community in social, economic, and cultural as very high economic value and tedong has the meaning of religion as in any death ceremony tedong be the primary measure of the ceremony as the sacrificial animals so tedong has a philosophical meaning, socio-cultural, economic, and religious.
\end{abstract}

Keywords-Tedong, symbolic meaning, Tana Toraja

\section{INTRODUCTION}

Some communities in Tana Toraja hold a belief called Aluk Todolok which means the rules of the ancestors. According to its adherents, Aluk Todolok was inherited by Puang Matua. Believers who worship, adore, and glorify Puang Matua (the Creator) embodied in various forms of life attitudes and ritual expressions or sacrificial offerings in ritual ceremonies. Aluk Todolok is not a single but classified into 3 (three) parts, namely Deata Langit (the custodian of the sky), Deata Kapadanganna (the custodian of the earth), and Deata Tangangana Padang (the custodian of the land). The worship of the three elements of Aluk Todolok adherents is conducted in the forms of ritual with various grains or sacrifices [1].

One of the forms of the grains in the belief of Aluk Todolok just as the ceremony Rambu Solo' (funeral) is Tedong (buffalo). Not all types of Tedong can be the offering/sacrifice but only those with specific motives. Tedong with certain types of the communities in Tana Toraja represents the philosophical value, socio-cultural, economic, and religion. Tedong (the name of buffalo) in Tana Toraja among social life and beliefs has a very high value in traditional ceremonies and rituals. Tedong sacrafice, involved in every rituals and customs, such as ceremonies Rambu Solo'. The number and the type of Tedong mark the family's social status in the social structure of cultural, economic of those who conduct the customary ritual ceremony. The economic value of Tedong ranges in hundreds of millions of Indonesian Rupiahs to half a billion, becoming the standard of various ritual activities of the tribes in Tana Toraja. Although its value is very expensive for families who conduct the ceremony, Rambu Solo' must be conducetd due to the rules of Aluk Todolok about tedong sacrifice among all the levels in society in Tana Toraja. Tedong becomes a major symbol of the offering, specified in ritual ceremonies, giving a legal sanction customary standard to become the standard inheritance.

Aluk Tudolok, among the society in Tana Toraja, puts Tedong as the fundamental of any ceremony, the term Tedong Garonto Eanan means, in performing rituals, even at the expense of sacrificial animals such as pigs and chickens, Tedong remains to be the main sacrificial animals and compulsory. Every class of society in Tana Toraja has rules in the matters of Tedong sacrifice as directed in Aluk Todolok. The classes of society in Tana Toraja is called Tana'. Tana' bulaan is the highest nobility as the heir to accept aluk unit as the regulator of the rules of life and the leader of religion; Tana' bassi, the intermediate level of nobles as the heir to receive the trust to organize leadership; Tana' Karurun, mostly a social class mandated as skilled people, and Tana' Kua-kua, the lowest class as the heir who must accept responsibility as a servant of the nobles [2]. The various levels of social Tana Toraja is closely related to the ritual ceremonies of death, standardized by the value of the Tedong as the sacrifices in any traditional rituals.

In the customary ritual of death for some people of Tana Toraja with Aluk Todolok belief, Tedong has several symbols and has become the main requirement of the funerals. Based on the data held by the Documentation section on Regent Office Tana Toraja, for the last 12 years the number of the execution of the death ceremony Rambu Solo' has as many as 1,273 (compiled from various data; 2015) times of the ceremony with the price of Tedong nearly 
half a billion Indonesian Rupiah, which shows that people in Tana Toraja have their own meaning and symbols in the ceremony of death, not only from material, but also philosophical, social, cultural, and religious aspects.

The change of symbolic meaning of Tedong in the society of Aluk Todolok belief in Tana Toraja South Sulawesi can be referred to Simmel and Mead's view of symbolic interactionalism. The view states that social reality emerges through the process of interaction, relating to symbolic media in the interaction and analysis of the human ability to create and manipulate symbols [3]. Blumer's assumptions of symbolic interactionism [4] indicate that human beings act toward the things based on their value; the meanings are the result of social interaction among society; meanings are modified and handled through the process of interpreting passages used by each individual in his involvement with the signs that he faces. Blumer assumptions are used to understand the changes of symbolic meaning of Tedong in Rambu Solo' ritual ceremonies among people with Aluk Todolok belief in Tana Toraja.

The advanced views to understand the meaning of Tedong in Rambu Solo' rituals among people of Tana Toraja belief of Aluk Todolok are referred to the view of [5] that there is no human without what is now classified by modern social scientists as "religion". Every society has some concepts of the supernatural order, spirits, and Gods. The combination of Weber's idea is the presence of the supernatural beings with an understanding of the symbolic character. Tana Toraja people in the rituals of death according to the value of the belief Aluk Todulok has made Tedong as well as the main symbol of sacrificial animals and the base in the ceremony as well as a symbol of social status and social structures in Tana Toraja Aluk Todolok adherents.

As a comparison, the study of symbolic meanings can be seen from the article of [6] who examined the symbolic meaning of batik in ancient Javanese society in which they found that batik motifs have symbolic meanings and can be used as both a mean to communicate to contemporaries and the social stratification. Similarly, the results of [3] research on the symbolic meaning of Umpasa, Sinamot, and Ulos on the Toba Batak Wedding Tradition, found that Umpasa. Sinamot, and Ulos have a symbolic meaning in traditional Batak marriage that is as a means of communication, money dowry, and "materei" so that the petition submitted to God Almighty becomes a reality along with the arrival of the Ulos. Related to this research, the symbolic meaning of tedong in the social structure of the Tana Toraja community, whether the types and motives of tedong in the customary ritual ceremony of Tana Toraja people adhering to the belief of Aluk Todolok as a means of connecting the world with the afterlife and also indicating the social level in Tana society Toraja. It is this culture according to the functional theory that there is some more or less unified knowledge, as pseudo knowledge, beliefs, and values and is a system of symbolic meanings, some of which define reality as it is believed, and others that determine normative expectations charged to humans [7].

The main problem of research is how the change of symbolic meaning of Tedong in Rambu Solo ceremony based on the belief of Aluk Todolok in social structure of
Tana Toraja community of South Sulawesi. While the purpose of the research is to understand the change of symbolic meaning of Tedong in Rambu Solo ceremony according to the value of Aluk Todolok in Tana Toraja society of South Sulawesi.

\section{RESEARCH METHODS}

The research approach used was descriptive qualitative to describe the phenomena and historical facts that exist, which took place at this time or in the past. The data were qualitatively sourced from extensive descriptions and strongly grounded, and contain an explanation of the processes occurring within the local sphere [8]. The type of research was field research (survey), especially at the time of death ceremony (Rambu Solo'). Data collection was done by collecting research data through observation and sensing in accordance with the problems and objectives of research and develop their own according to the needs of the field [9], in-depth interviews, and documentation with the focus of research on the meaning of tedong in traditional ritual ceremony (Rambu Solo' = death ceremony) Tana Toraja people adhering to the beliefs of Aluk Todolok. The researcher, as the main instrument of research, interacted with informants and feel meaning. The data collected (verified) was called source criticism because each source had an external aspect (true source) and internal (providing information as needed) [10]. The result of source verification or criticism was followed by the interpretation of facts, because facts were symbols or representatives rather than something that had actually existed, had an objective reality of their own [11]. Data validation was done by extension technique of observation, increasing perseverance, holding member chek, and triangulation [12]. The result of interpretation was written (historiography) as the culmination of everything in historical research methods by trying to capture and understand history as it happened [13].

\section{RESULTS AND DISCUSSION}

The regency of Tana Toraja with the capital of Makale is geographically located in the north of South Sulawesi Province. Administratively covers 19 districts, 112 Lembang, and 47 urban villages covering an area of 2,054.30 $\mathrm{km}^{2}$. The population reached 240,249 people with population density of 117 people $/ \mathrm{km}^{2}$. Tana Toraja is known as an area with a distinct social and cultural life especially in its belief system.

In the social and cultural system of the Tana Toraja community or territory deployed by the term Tondok Lili'na Lapan Tana Matari 'Allo (a round country like the moon and the sun), the national alliance is a unified entity of the various customary areas, not governed by a single ruler, but his land (Tana ') consists of customary groups ruled by each customary stakeholder, consisting of 32 adat stakeholders, with a population of approximately 240,249 Souls with the Majority of Toraja ethnicity and Toraja local languages. The Tana Toraja community has a traditional belief system that lives in Tana Toraja society in the form of belief that is 'Aluk Todolok'. This belief implies that the Toraja ancestors came from heaven using a ladder (path = aluk) which was then used by the Torajans as a way of relating to Puang Matua 
(God the Creator). Aluk is not only a belief system but a combination of tradition, religion, and law, because it governs the life of the society. One common law of aluk in aluk belief is the separation of ritual ceremonies of death (Rambu Solo ') and life (Tuka Rambu'). Both ceremonial rituals are equally important, especially in the forms of serving offerings in traditional ritual ceremonies in accordance with the belief of Aluk Todolok where tedong becomes the main sacrificial animal.

Religion is a system of symbols that serves to reinforce a strong, deep, and unflagging mood and motivation in human beings by formulating conceptions of the general order of existence and enveloping the conception with an aura of actuality for feelings and seeming motivations as reality [14]. This view can be used to understand beliefs (customary religion) for people in Tana Toraja. Devices of socio-cultural values for the people of Tana Toraja can be seen through the traditional ceremonial system. Until this decade, the people of Tana Toraja still maintain it despite some changes in meaning, especially social and economic meaning, including performing various ritual ceremonies. However, the people classify them in 2 (two) traditional ceremonies or rituals namely Rambu Solo 'and Rambu Tuka' [15]. The Rambu Solo ceremony stems to the belief that a newly deceased person should not be buried immediately. His body is still bound by various provisions, both ritual and custom, except the newborn child who died, then immediately buried in a growing tree trunk (Liang Pia) or buried in the ground [16].

The adherence and persistence of the Tana Toraja community of Aluk Todolok's belief in the customs and cultural system can be seen in the Rambu Solo 'ceremony. The death ceremony which means the fire of the offering sacrifice is brought to the deceased or whose death is celebrated. Rambu Solo 'is called Aluk Rampe Matampu because the ritual ceremony of offerings is done when the sun has started to fall and is done in the west of Tongkonan house (Toraja custom house). Traditional ritual ceremony Rambu Solo 'is also an offering ceremony to bring the spirits to the south, based on the belief that the soul is in the south. The sign of Solo can also be interpreted as the only way to the country of origin, to bring the corpse back to the sky.

The people of Tana Toraja have social or social strata namely (1) Tana 'Bulaan or nobility class; (2) Tana 'Bassi or the middle-class nobility; (3) Tana 'Karurung or the common people / free people; and (4) Tana 'Kua-Kua or servant class [17]. This social level affects the implementation of traditional ritual ceremonies of death or Rambu Solo 'which are: (1) the Tana' Kua-Kua community; for the child who died in the womb, then the time of birth is immediately buried (dipasilamun toninna); for children who die while in teething, it must be buried when the sun is set on the condition that it is enough to hit the feeding place (preferably in a manger); buried with chicken eggs (dipasalamun Tallo' manuk); the execution of his burial with a pig (dibai tungga') by using an erong or coffin; (2) Tana 'Karurung Group; there are several levels of death ceremonies; Ditedong tungga; the corpse was kept in the house for a day and was buried in the afternoon with the sacrifice of a tedong and a few pigs; Dipasang bongi, the burial time sacrificed with two pigs; Disilik, the ceremony of death in children (teeth have not grown and noble children) then entitled to be given a tedong and a few pigs; Ma'tangke Patomali, the ceremonial death of a noble boy with two tedongs and a few pigs; (3) Tana 'Bassi community group; known by three levels of ceremony namely; Dipatalungi bongi (three nights). Its implementation for three consecutive nights by sacrificing three tedongs and pigs to taste; Dipalimang bongi (five nights). The five-night ceremony with five sacrificial tedongs and pigs and the Dipapitung bongi ceremony took place for seven nights with tedong and pork to taste; (4) Tana 'Bulaan community group, the death ceremony, where the corpse is kept long (ra'pasan) above traditional house (tongkonan), the implementation is done twice; In Aluk pia, the ceremony is held in tongkonan and aluk rante, the ceremony is held in the field (rante) with the completeness of several needs such as tower (lakkean) two-floor with ten meters high and shaped tongkonan house [18].

The implementation of the death ceremony (Rambu Solo ') with the terms attributed to the number of death ceremonies during the last twelve years amounted to 1,273 times of ceremony. In accordance with the rules / customs of the beliefs of Aluk Todolok, then every tedong ceremony becomes the main condition in the implementation of the ritual ceremony. Thus, many tedongs and pigs became sacrificial offerings in the execution of the ceremony. In this ceremony, Tedong symbolically symbolizes the meaning of ritual ceremonies in Torajan society that last up to this decade in accordance with the social level in society, as well as being a unique social, cultural, economic and religious value for the people of Tana Toraja.

Tedong has a symbolic meaning in every ceremony of Tana Toraja people, especially the believer of Aluk Todolok, because the believer's community has the belief and belief that by holding a traditional ceremony, the spirit of the dead can be accompanied to the nirvana of immortality in which one of the symbols is the buffalo as the main condition in the ceremony the death of Rambu Solo' [18].

Tedong has a philosophical significance for the Tana Toraja community as being the main symbol of the offering in the worship ceremony and offerings for Puang Matua (the Creator) as a symbol of prosperity, work and leadership of the Toraja [18]. Tedong has meaning prosperity for Tana Toraja society because Tedong has high economic value; the more Tedong ownership and sacrifice, the more prosperous. Tedong means work, because tedong is well maintained and treated like a human being. Tedong means leadership because the sacrificial tedong signifies a person's social status as well as signifies a person's leadership based on his social status. Tedong is socially and culturally meaningful, as it becomes a symbol of social status for the Tana Toraja community of Aluk Todolok believers, the more Tedong sacrificed as offerings at the Rambu Solo ceremony signifies the higher the social status of a person or family. Tedong also means cultural, because Tedong serves as a preserver of Tana Toraja cultural community, where before the sacrificial animal is sacrificed to sacrifice animal, hence previously performed cultural ceremony. In the Tana Toraja community, Mappasilaga is known for its cultural art. Mappasilaga is a buffalo race to be presented in a ritual custom ceremony. The art of cultural mappasilaga for the people of Tana Toraja, has become hereditary from the ancestors of the adherents of Aluk Todolok teachings and even regarded as a cultural preservation, has also become a spectacle to foreign countries because at the time of the 
implementation of the Rambu Solo' ceremony previously performed mappasilaga tedong. Documentation of the Office of the Regent of Tana Toraja recorded during the last twelve years, there are 1,273 execution of mappasilaga Tedong in accordance with the number of ritual ceremonies performed (Rambu Solo').

Tana Toraja community adherents of beliefs Aluk Todolok also assume that sacrificing tedong contains the meaning of socializing shame. The procurement of tedong in every ceremony, especially Rambu Solo 'means society has siri' value or shame, every citizen of Tana Toraja seeks to hold tedong in ceremony, although value or price is expensive because it can lift siri 'value and social status of a person or family as the forming of the social structure of society. The honor for the Tana Toraja community remains highly respected, because the one who violates it will be ostracized by other family members, so that if there is a family that is dying, then the families shoulder to help each other for the purposes of the ritual ceremony. The type and form of the donation will be recorded by the families who died due to the opposite if the donating family is dying, it will be donated according to what was previously donated. This is what means that tedong is the standard value of legal sanction for the people of Aluk Todolok belief.

Self-esteem of the Tana Toraja people is well preserved. Not keeping self esteem or siri' can be considered a form of adat violation with the consequence of being ostracized from the family. This, in turn, encourages motivation to work hard and improve performance so as to give sacrifice during the death ceremony (Rambu Solo'). Thus, siri' means dignity and pride. Tedong procurement is a form of enforcing siri' in order to obtain social status. If there is no Tedong in the ritual ceremony, the family will feel embarrassed in front of other members of the locals or even ostracized. Not all social levels in the Tana Toraja community of Aluk Todolok believers can sacrifice certain types of tedongs in traditional ceremonial rituals such as Tana' Kua-Kua (group of slave sage) offspring that cannot sacrifice tedong saleko, bonga, lotong boko, sokko, and tedong bulan because this group cannot perform the Rambu Solo' ritual ceremony. However, they can only worship in three consecutive days and nights and cut off some tedong pudu, pig and chicken, which is set in the Aluk rule.

Tedong is worth the religion because according to the rule of belief on Aluk Todolok, the dead are traveling by riding tedong to the afterlife. Tedong is considered the descendant of the supreme god (Puang Matua). Tedong offerings in the ceremony, before being presented are decorated and paraded and recited passomba tedong (poetry or chanting sung together to honor the spirit of Puang Matua descent), after arriving at Rante (the house of worship) tedong sacrificed and must fall to the right side, because if falling to the left side, it indicates a bad address for the inhabitants of the kampung. The head of Tedong is left intact to be made an offering for the spirits placed on a banana leaf, and the family conducting the ceremony does not eat it.

The meaning of tedong in the religious ceremony of the Tana Toraja people of the belief of Aluk Todolok is the most special riding of the spirits, especially the tedong bonga and the other black tedong which guard and accompany the spirit journey to the nirvana of eternity. The more tedong offerings the sooner the sin is erased and to have a place in the sight of God, the more tedong that is dedicated will symbolize the worthiness of life of the deceased in the afterlife, guarding the salvation of the spirit into the natural world of nirvana and keeping the serenity of the abandoned family. Tedong offerings in traditional ritual ceremonies in a family can be seen from the composition of tedong head / horns that exist in the houses (tongkonan) Tana Toraja community. The more horns displayed on tongkonan signify the social level of the tedong sacrifice to the family.

Tedong has economic value; therefore Tana Toraja people who have tedong are people who have financial capacity. Tedong affects the social status of Tana Toraja people economically. The price of a particular tedong is very expensive as it can reach one billion or more per head. Each type of tedong has economic value, such as tedong Saleko (Rp 160 million - 420 million); tedong Bonga (Rp 40 million - Rp 160 million); tedong Pudu (Rp 12 million - Rp 75 million); tedong Sokko (Rp 35 million - Rp 125 million); tedong Lotong Boko (Rp 300 Million); tedong Moon (IDR 2 Million - 10 Million). The high price of tedong indicates that the ritual ceremony of death (Rambu Solo ') in Tana Toraja requires a very expensive cost, depending on the social level of the community. As a comparison with the results of other studies conducted by [15] about the level of buffalo strata and buffalo prices in the Tana Toraja community can be seen in the following table:

TABLE I. LEVELS OF STRATA TEDONG PRICES TORAJA BUFFALO

\begin{tabular}{|c|c|c|c|c|}
\hline $\begin{array}{l}\text { Depth } \\
\text { Strata }\end{array}$ & $\begin{array}{c}\text { Type } \\
\text { Tedong }\end{array}$ & $\begin{array}{c}\text { The } \\
\text { divisio } \\
n \\
\text { Tedong }\end{array}$ & $\begin{array}{c}\text { Characteristics } \\
\text { Tedong }\end{array}$ & $\begin{array}{l}\text { Price } \\
\text { range }\end{array}$ \\
\hline 1 & $\begin{array}{l}\text { Samba } \\
\text { o } \\
\text { (Brown } \\
\text { / gray) } \\
\end{array}$ & - & $\begin{array}{lr}\text { Gray } & \text { skin } \\
\text { color } & \text { with } \\
\text { golden } & \text { yellow } \\
\text { fur } & \\
\end{array}$ & $\begin{array}{l}\text { 10-20 } \\
\text { Million }\end{array}$ \\
\hline \multirow[t]{2}{*}{2} & $\begin{array}{l}\text { Pudu ' } \\
\text { (black) }\end{array}$ & $\begin{array}{l}\text { Pudu } \\
\text { 'Balian }\end{array}$ & $\begin{array}{l}\text { Downstairs } \\
\text { there are white } \\
\text { ears, eyes } \\
\text { bongek }\end{array}$ & $\begin{array}{l}25-100 \\
\text { Million }\end{array}$ \\
\hline & & $\begin{array}{l}\text { Pudu } \\
\text { 'Panglo } \\
\text { li }\end{array}$ & White tail & $\begin{array}{l}50-100 \\
\text { Million }\end{array}$ \\
\hline 3 & Todi & - & $\begin{array}{l}\text { White among } \\
\text { the horns, tail } \\
\text { must be white }\end{array}$ & $\begin{array}{l}30-100 \\
\text { Million }\end{array}$ \\
\hline \multirow[t]{3}{*}{4} & $\begin{array}{l}\text { Bonga } \\
\text { (Stripe) }\end{array}$ & $\begin{array}{l}\text { Bonga } \\
\text { relapse }\end{array}$ & $\begin{array}{l}\text { The white } \\
\text { color only } \\
\text { snout to the } \\
\text { eye }\end{array}$ & $\begin{array}{l}80-200 \\
\text { Million }\end{array}$ \\
\hline & & $\begin{array}{l}\text { Bonga } \\
\text { usual }\end{array}$ & $\begin{array}{l}\text { Head and } \\
\text { black body } \\
\text { and white legs }\end{array}$ & $\begin{array}{l}\text { 100-200 } \\
\text { Million }\end{array}$ \\
\hline & & $\begin{array}{l}\text { Bonga } \\
\text { old }\end{array}$ & $\begin{array}{l}\text { White head } \\
\text { except } \\
\text { eyebrows, and } \\
\text { white are not } \\
\text { up to the neck }\end{array}$ & $\begin{array}{l}120-300 \\
\text { Million }\end{array}$ \\
\hline
\end{tabular}




\begin{tabular}{|c|c|c|c|c|}
\hline & & $\begin{array}{l}\text { Bonga } \\
\text { tengek }\end{array}$ & $\begin{array}{l}\text { Chest, neck } \\
\text { and } \\
\text { white, black } \\
\text { eyebrows, tail } \\
\text { and white } \\
\text { nails }\end{array}$ & $\begin{array}{l}200-400 \\
\text { Million }\end{array}$ \\
\hline \multirow[t]{2}{*}{5} & Saleko & $\begin{array}{l}\text { Saleko } \\
\text { ta'pi }\end{array}$ & $\begin{array}{l}\text { Motif spotting } \\
\text { the shoulders, } \\
\text { head, chest } \\
\text { and abdomen }\end{array}$ & $\begin{array}{l}200-01 \\
\text { billion }\end{array}$ \\
\hline & & $\begin{array}{l}\text { Regular } \\
\text { Saleko }\end{array}$ & $\begin{array}{l}\text { Between white } \\
\text { and black } \\
\text { motif balanced }\end{array}$ & $\begin{array}{l}200-01 \\
\text { billion }\end{array}$ \\
\hline 6 & $\begin{array}{l}\text { Lotong } \\
\text { boko }\end{array}$ & - & $\begin{array}{l}\text { There are only } \\
\text { black in the } \\
\text { back / neck }\end{array}$ & $\begin{array}{l}400 \text { to } \\
1.5 \\
\text { billion }\end{array}$ \\
\hline
\end{tabular}

Source: Research Findings of Ikhwanussafa Sadidan, et al (2015)

Some of the findings of the traditional ritual ceremonies, usually sacrificing ten to hundreds of tedongs in a ritual ceremony of death (Rambu Solo'). At first tedong sacrifice in Tana Toraja society is determined by social status or social level of society, but in its development experience change, especially influence of education level of society and economy. Tedong has symbol or meaning economically for Tana Toraja society because it determines in the stage of burial ceremony (Rambu Solo '); the value of Kapa (standard of customary law sanction of marriage) based on social level (Tana'); standard value for sale and purchase and transportation; and Mana 'value (standard for inheritance division). The economic significance of the high cost used in the Rambu Solo 'death ceremony is family gathering, social strata identity, and family debt [18]. In addition, the ceremony of the death of Rambu Solo which sacrifices tedong whose economic value is very high, also contains the meaning of (1) as a unifying container of the family, (2) as a place of dividing inheritance, (3) as a place of pronouncement of dignity, (4) (5) as a forum for art development, and (6) as a donating vessel [15].

\section{CONCLUSION}

The results show that tedong in Tana Toraja community adherents of Aluk Todolok beliefs has a symbol or a very high meaning. The philosophical meaning of tedong for the Tana Toraja community is as the main symbol of the offering of traditional ritual ceremonies intended for Puang Matua (the Creator) as a symbol of prosperity, work (motivation), and leadership; symbolic meaning tedong economically is as the level of funeral ceremony (Rambu Solo ') value (Kapa) standard sanctions customary law of marriage according to Tana' (Social rank); value of buying and selling standard; and value (Mana ') standard inheritance division. Tedong also has a social-cultural significance for the Tana Toraja community to be social status according to social level (Tana'), the more tedong sacrificed, the higher the social status; meaningful culture because it serves as a cultural preserve, is used for the activities of Mappasilaga (buffalo fight) which will be presented in traditional ritual ceremonies; tedong means to embarrass the sacrifice of sacrifice tedong in the ceremony of death (Rambu Solo') means to enforce the value of siri' (shame) in society, because for those who do not sacrifice will be subject to legal sanction in the family that is ostracized in the family.

\section{ACKNOWLEDGMENT}

Thanks to the Dean of the Faculty of Social Sciences who have provided financial support for this research.

\section{REFERENCES}

[5] M. Weber, The sociology of religion. Beacon Press, 1993.

[6] S. Maziyah, M. Mahirta, and S. Atmosudiro, "Symbolic Meaning of Batik in Kuna Javanese Society (Makna Simbolis Batik pada Masyarakat Jawa Kuna)," Paramita Hist. Stud. J., vol. 26, no. 1, pp. 23-32, 2016.

[7] T. F. O'dea and J. O. Aviad, The sociology of religion. Prentice Hall, 1983.

[8] U. Silalahi, "Social Research Methods," Bandung, Refika Aditama, 2009.

[9] B. Bungin, "Qualitative Research: Communication, Economic, Public Wisely and Social Knowledge," Kencana Media Group, Jakarta, 2010.

[10] C. Frankfort-Nachmias and D. Nachmias, Study guide for research methods in the social sciences. Macmillan, 2007.

[11] L. Gottschalk, "Understanding History: a Primer of Historical Method, Terj," Nugroho Notosusanto, Cet. IV, 1986.

[12] L. J. Moleong, "Methodology of Qualitative Research," Revis. Ed. Bandung Remaja Rosdakarya, 2008.

[13] H.-P. Blossfeld, A. Hamerle, and K. U. Mayer, Event history analysis: Statistical theory and application in the social sciences. Psychology Press, 2014.

[14] B. Morris, Anthropological studies of religion: An introductory text. Cambridge University Press, 1987.

[15] A. Ansaar, "Rapasan: Funeral Ceremony For Tana'bulaan Caste In Tana Toraja (Rapasan: Upacara Pemakaman Bagi Kasta Tana'bulaan Di Tana Toraja)," Walasuji, vol. 5, no. 2, pp. 225$238,2014$.

[16] K. M. Adams, "More than an ethnic marker: Toraja art as identity negotiator," Am. Ethnol., vol. 25, no. 3, pp. 327-351, 1998.

[17] K. M. Adams, "Club Dead, Not Club Med: Staging Death in Contemporary Tana Toraja (Indonesia)," Southeast Asian J. Soc. Sci., vol. 21, no. 2, pp. 62-72, 1993.

[18] M.-T. Tsai and A. Sugiharto Wonodihardjo, "Achieving Sustainability of Traditional Wooden Houses in Indonesia by Utilization of Cost-Efficient Waste-Wood Composite," Sustainability, vol. 10, no. 6, p. 1718, 2018. 